\title{
Current-Account Imbalances and Economic Growth During the 2008-2009 Financial Crisis: an Empirical Analysis
}

\author{
Rossitsa Rangelova'
}

\begin{abstract}
This study examines the relationship between current-account imbalances and economic growth during the 2008-2009 financial and economic crisis for 179 countries (covered by IMF data) and within the EU-27 countries (covered by Eurostat data). The countries are divided into 4 groups by GDP per capita based on PPPs, namely, low income, lower middle-income, upper middle-income and high-income countries. Empirical analysis is applied, including descriptive statistics and regression estimates. Statistical data are used, including the average of the GDP growth rate in the years prior to the crisis (2003-2007), the average of the GDP growth rate for 2008 and 2009, current account as a percentage of GDP, and the level of average inflation. It is proved that, in general, the 2008-2009 crisis affected high- and upper middle-income countries more than poorer countries. Within the EU-27 countries, however, the crisis appears to have affected lower income countries more than higher income countries. A common tendency is observed for the two country samples: countries that experienced strong growth just prior to the crisis had an increased risk of suffering after the crisis. The boom prior to the crisis led to imbalances that rendered economies more vulnerable. Additionally, surpluses that existed prior to the crisis are an important risk factor for the two groups of countries.
\end{abstract}

KEY WORDS: $\quad$ current-account imbalances; economic growth; 2008-2009 financial and economic crisis; EU countries; global scale

JEL Classification: F32; F41; F43

1 Bulgarian Academy of Sciences, Bulgaria

\section{Introduction}

There is a growing literature on the various impacts of the 2008-2009 financial and economic crisis in countries around the world. The main fields of study are the crisis' impacts on commodity-producing countries, world trade, countries with close trade linkages with

Correspondence concerning this article should be addressed to: Rossitsa Rangelova, Bulgarian Academy of Sciences PO Box 788 3, Aksakov Street 1040 Sofia Bulgaria E-mail: r.rangelova@iki.bas.bg the United States (US) or China, and countries that rely heavily on remittance flows from developed countries and others.

Some researchers are interested in calculating changes in Gross Domestic Product (GDP) growth during the crisis resulting from changes in non-financial sectors and branches, as well as from foreign trade activity. As far as trade balance is typically the largest component of the current account balance, the dependence of the latter indicator on GDP is important.

It is observed that global current-account imbalances have worsened to an unprecedented degree 


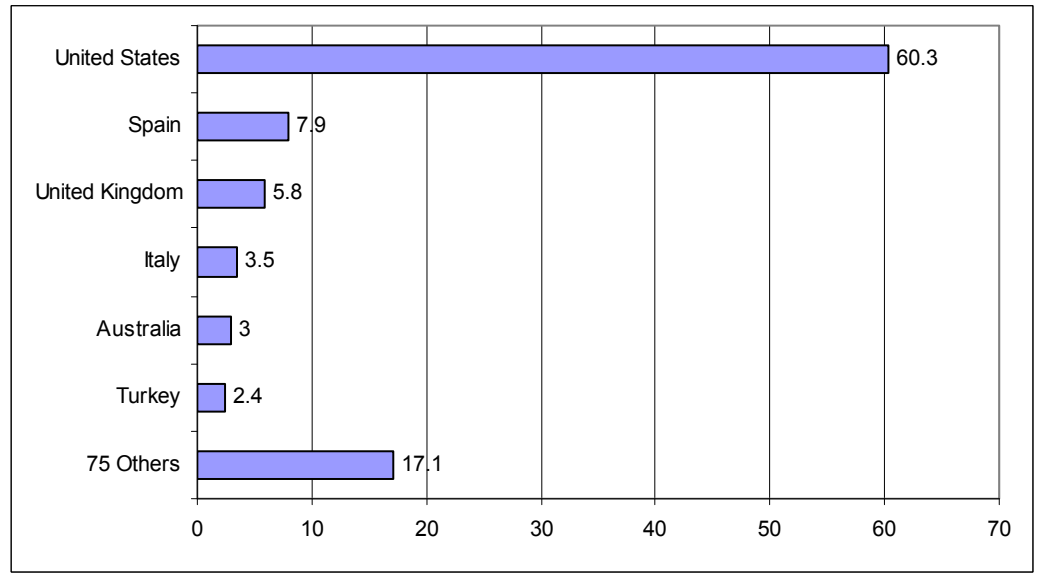

Figure 1. Current-account deficit countries, 2006 (\% of aggregate deficit). Adapted from World Bank, 2014a

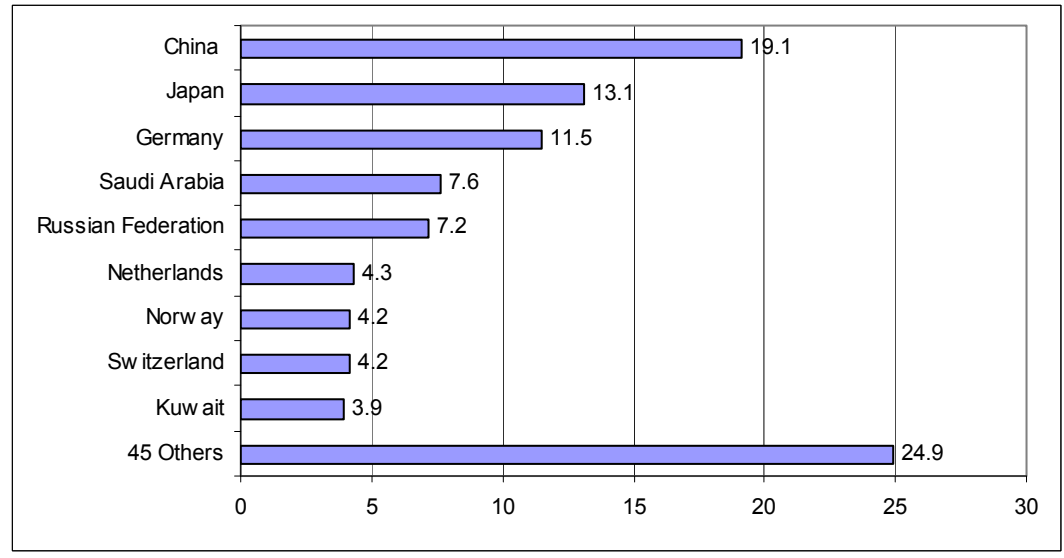

Figure 2. Current-account surplus countries, 2006 (\% of aggregate surplus). Adapted from World Bank, 2014a

over the past decade. Global imbalances have contributed to the financial crisis and the subsequent global "Grand Recession." What is the relationship between the current-account imbalances and economic growth both at a global scale and within the EU countries during the 2008-2009 crisis? The present paper answers this question.

\section{The global framework of current- account imbalances}

Current-account imbalances reflect the complex activity of macroeconomic and financial mechanisms. At a global scale, there is no reason for current accounts to be balanced. Global imbalances are normally understood as the compensation (combination) of high and 


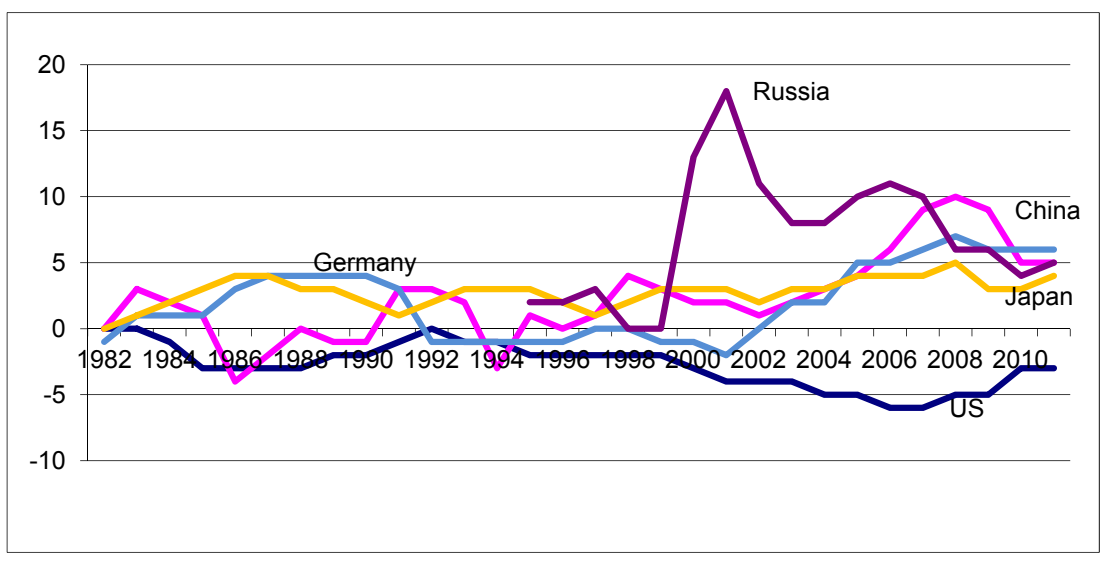

Figure 3. Current-account balance, 1980-2010 (\% of GDP). Adapted from World Bank, 2014a

increasing current-account surpluses of some countries and the large current-account deficits of others, mainly the United States, along with some other smaller-deficit countries (Figure 1). At the peak of the imbalances in 2006, the United States absorbed $60.3 \%$ of all surpluses. There were a few other developed economies besides the United States in the group of large-deficit countries (namely, Spain, the United Kingdom, Italy, Australia and Turkey), which had a combined share of $22.6 \%$ of deficits, and 75 small, mainly developing countries, which accounted for another $17.1 \%$ of deficits.

The main surplus countries were China, Japan, Germany and six other countries, four of which are oil exporters. The other two countries - the Netherlands and Switzerland - are not oil exporters, but they generated $75 \%$ of all surpluses before the crisis (Figure 2). Like China, but on a smaller scale, many developing countries have built currency reserves that are invested mainly in United States Treasury bonds (Priewe, 2010). China's much-discussed surplus accounted for $19.1 \%$ of the aggregate surplus, while Japan and Germany together accounted for nearly $25 \%$. There were also 45 small, mainly strongly performing developing countries that accounted for the remaining approximately quarter of total surpluses.

Considering long term trends, the United States deficit grew continuously from 1991, reaching a peak in 2006 (Figure 3). Since around 1990, the United States has become an ever-growing net debtor country with a net debt of approximately $20 \%$ of GDP prior to the crisis. During the crisis, imbalances shrank due to the sharp drop of imports in GDP and the increase in household savings. However, imbalances are projected to grow again. The bilateral China-United States trade deficit accounts for approximately $30 \%$ of the total deficit. Never before had there been global imbalances of this magnitude (Priewe, 2010). The other three countries shown in Figure 3 (Russia, Germany and Japan) had current account surpluses over the first several years of the new century.

Among the countries with current account surpluses, the role of the big oil exporters and the European countries is evident, as is the sharply increasing role of China. The United States has the largest current account deficit, although this deficit declined slightly just prior to the crisis. Japan, whose deficit has remained nearly constant, clocks in at number 2, followed by the rest of the world and the European countries, whose deficits have increased, particularly in 2008.

Traditionally, the surplus countries mark higher GDP growth, as in the case of China, Russia, and others, in contrast to the deficit countries, such as the United States (Figure 4). 


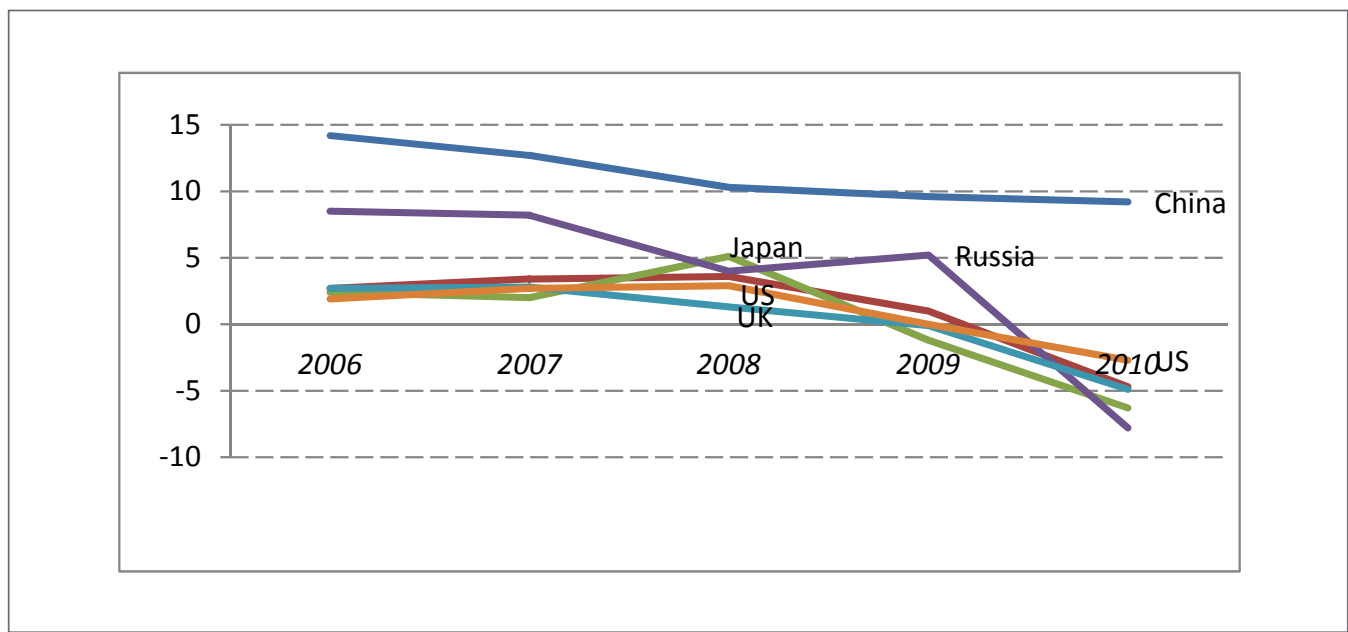

Figure 4. Annual GDP growth rate in selected countries, 2006-2010 (\%). Adapted from World Bank, 2014b

Table 1. Average current account balances (in \% of world GDP)

\begin{tabular}{lccc}
\hline & $\mathbf{2 0 0 5 - 2 0 0 8}$ & $\mathbf{2 0 0 9}$ & $\mathbf{2 0 1 0 - 2 0 1 4}$ \\
\hline Current account deficit & & & -0.6 \\
\hline United States & -1.4 & -0.6 & -0.5 \\
Peripheral Europe & -0.8 & -0.5 & -0.4 \\
Rest of the world & -0.3 & -0.4 & \\
& & & 0.9 \\
Current account surplus & & 0.6 & 0.2 \\
\hline China & 0.6 & 0.3 & 0.2 \\
Emerging Asia & 0.2 & 0.2 & 0.7 \\
Japan & 0.3 & 0.3 & 0.5 \\
Oil exporters & 1.0 & 0.4 & 0.9 \\
Core Europe & 0.7 & & 0.2 \\
Discrepancy & & & \\
\hline
\end{tabular}

Note: Adapted from Blanchard, Milesi-Ferretti, 2009 p. 12

Blanchard O. and G. M. Milesi-Ferretti pay attention to the fact that these imbalances, primarily reflecting distortions both at the domestic and international levels, are particularly strong from 2001 onwards (Blanchard \& Milesi-Ferretti, 2009). Before the 20082009 crisis, there were strong arguments for reducing global imbalances. The two authors are interested in the evolution of imbalances over time. Taking into ac- count the influence of a variety of factors, they provide projections of current account balances up to 2014, including countries with current-account deficits that maintain their positions (Table 1). They foresee that among the countries with current account surpluses, China and oil exporters will increase their surpluses (together with insignificant increases in Core Europe) and thus world discrepancy will increase. 


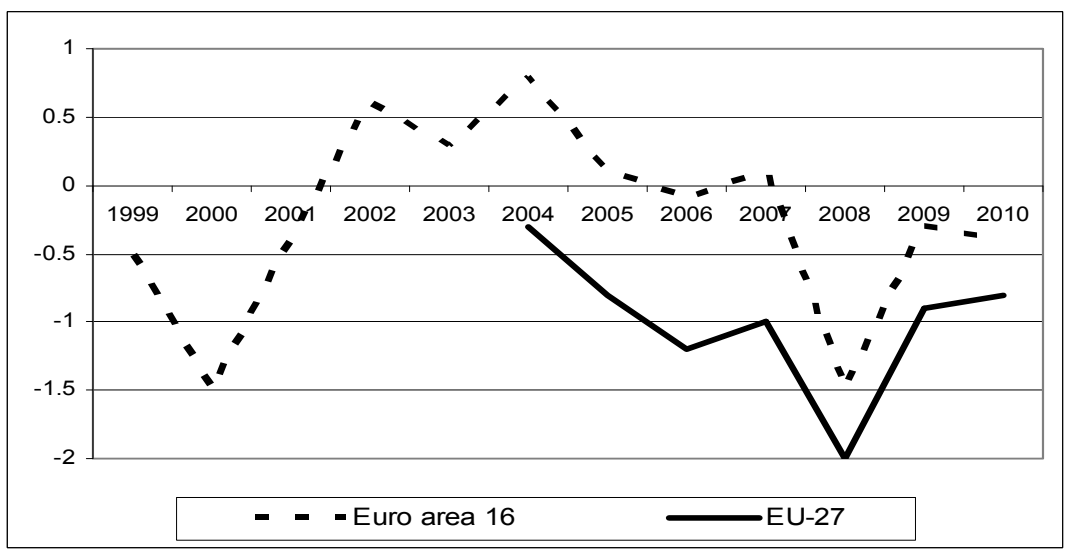

Figure 5. Balance of the current account, EU, 1999-2010, (\% of GDP). Adapted from OECD, 2012

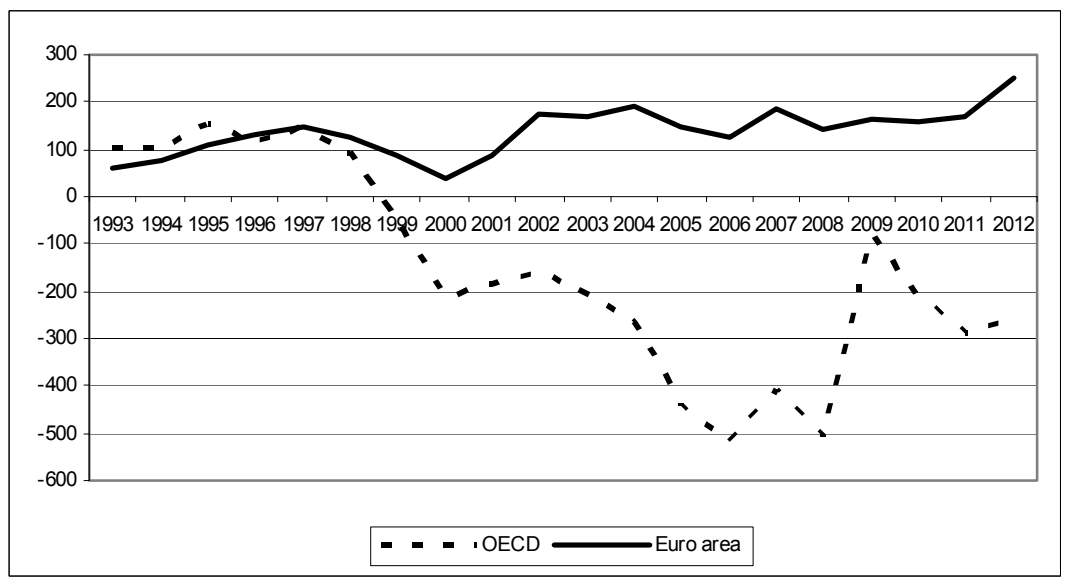

Figure 6. Trade balance of goods and services in OECD and Euro area, 1993-2012. Adapted from OECD, 2012

Current-account imbalances among the EU-27 countries. Germany, together with three smaller EU member states (Austria, Finland, and the Netherlands), has maximized its current-account surplus through wage and fiscal restraint (thereby minimizing domestic demand growth), whereas other countries have become overly indebted and lost international competitiveness. This situation favors EU-16 development over EU-27 development (Figure 5).

The EU-16's economic development from the mid-1990s onwards has contributed to an increasing positive trade balance, in contrast to other developed country groups, such as the OECD (Figure 6).

Empirical analysis of the relationship between current-account imbalances and economic growth during the 2008-2009 crisis 


\section{A. Descriptive statistics}

It is relevant to start the analysis by taking a brief look at the data. At the beginning of the crisis, analysts often argued that emerging market economies and developing countries should be examined separately from developed economies, particularly the United States, due to the particularities of these groups of countries. In fact, some emerging market economies have performed much better than countries in other parts of the world. Asian countries have managed to recover very quickly and briskly from the crisis, with parts of Latin America following. In contrast, economic data for most of the members of the Commonwealth of Independent States (CIS) and the New Member Countries (NMCs) of the European Union (EU) have shown few real improvements. Additionally, the United States and the Western European industrialized economies have proved to be laggards with their vulnerable economic recoveries (International Monetary Fund [IMF], 2010).

To determine the negative impact of the crisis on economic growth, the following statistical indicators are used:

- The average of the GDP growth rate in the years prior to the crisis (2003-2007).

- The simple average of the GDP growth rate for the years 2008 and 2009. Looking at both years together provides a better picture than looking only at 2009, the year that most of the decline occurred.

- The percent change in the GDP growth rate between 2008 and 2009 compared to that between 2003 and 2007.

However, beyond these regional features, the impact of the crisis has clearly varied with the state of development of the economies in question. On examining the different categories of countries, the EU-27 countries are divided into 4 groups by GDP per capita (in EUR by PPS - EKS method, which means GDP based on PPP calculated using Elteto-Köves-Szulc's method):

- Low income countries (less than 15,000 EUR): Bulgaria, Latvia, Lithuania, Poland and Romania.

- Lower middle-income countries (between 15,000 and 20,000 EUR): the Czech Republic, Estonia, Hungary, Malta, Portugal, and Slovakia.

- Upper middle-income countries (between 20,001 and 25,000 EUR): Greece, Cyprus, and Slovenia.
- High income countries (over 25,000 EU): Austria, Belgium, Denmark, Finland, France, Germany, Ireland, Italy, Luxembourg, the Netherlands, Spain, Sweden, and the United Kingdom. These countries represent the so-called old EU-15 without Greece and Portugal and are the core of the Euro area (17).

Dullien uses an approach similar to the one in this study (Dullien, 2010). Dullien's objective was to determine whether a country should have approached the IMF to cover its finances during the recent crisis. Based on economic data for 179 countries covered by the World Economic Outlook of the IMF, Dullien attempted to determine which macroeconomic features rendered some countries more resilient in the face of the financial and economic crisis than others. In his econometric analysis, Dullien includes not just GDP growth rate, GDP per capita, current-account balances, and inflation as independent variables but also capital account openness, a dummy for a 2009 IMF program, and dummies for the different types of exchange rate regimes. Dullien concluded that being forced to accept IMF lending can be viewed as a sign that a country had been severely affected by the crisis. The author found that countries that use currency boards suffered much more as a result of the crisis than countries with other exchange rate regimes. Financial openness appears to have increased the risk of experiencing a deep recession, whereas higher inflation prior to the crisis seems to have mitigated its impact.

What are the peculiarities of the two samples? The 179 countries represent a global size scale, including very powerful countries, such as the United States (where the crisis began as a sub-prime lending crisis), China, Russia, India, and Brazil, and very poor countries. This means that there is a tremendous disparity across levels of economic development. The sample includes a large number of developing and less developed countries that have not been influenced by the current economic crisis (Ocampo et al, 2010). The other sample, that of the EU-27 countries, encompasses a more homogenous group of countries located within Europe that includes some of the most developed countries in the world (e.g., Luxembourg, Germany, France, and the United Kingdom) and also the less developed sub-group of the 12 NMCs from Central and Eastern Europe. 
Table 2. Average inflation by GDP per capita position of countries, 2007, \%

\begin{tabular}{lclc}
\hline EU-27 & \multicolumn{3}{l}{ 179 countries } \\
\hline GDP per capita - EUR in PPS & Average inflation & GDP per capita - USD & Average inflation \\
\hline Less than 15,000 (5) & 6.20 & Less than 976 & 8.4 \\
Between 15,000 and 20,000 (6) & 3.77 & Between 977 and 3,855 & 6.8 \\
Between 20,001 and 25,000 (3) & 3.00 & Between 3,856 and 11,905 & 6.3 \\
More than 25,000 (13) & 2.09 & More than 11.905 & 3.3 \\
\hline
\end{tabular}

Note: For EU countries, the author's calculations are based on Eurostat data. For the 179 countries: Dullien, S. (2010, 99-147).

The 179-country sample yields representative results for the so-called average of the global relationship between current account imbalances and economic growth, whereas the second sample, reflecting specific relationships between European countries, yields more efficient results for a homogeneous group of developed countries.

Later in this paper, where relevant, the findings of this study for the EU-27 countries will be compared with Dullien's findings.

The two studies are based on data assembled from various sources. Data for the EU are taken mainly from Eurostat, and data on GDP are obtained through PPS (EKS method). Dullien took data on GDP, inflation and current accounts from the IMF's World Economic Outlook database (January 2010). Dullien's sample contains 179 countries.

Dullien also defined four country groups: low income countries (GDP per capita below 975 USD), lower middle-income countries (GDP per capita between 976 USD and 3,855 USD), upper middle-income countries (GDP per capita between 3,858 USD and 11,905 USD) and high income countries (GDP per capita more than 11,905 USD). Dullien found large variations in the decrease in growth between the years 2003-2007 and 2008-2009. High income countries experienced a decrease in the growth rate of 5.2 percentage points and 5 upper middle-income countries saw a nearly equally large decrease of 4.9 percentage points in the growth rate. Lower middle-income countries saw growth decline by 2.7 percentage points and lower income countries by 1.2 percentage points. The high income countries were the only ones to record an average annual negative growth rate of $0.7 \%$ for the years 2008 and 2009. Therefore, high income countries were solely responsible for the contraction of world GDP in 2009.
All of the countries in our EU-27 sample had an average positive growth rate for the period 2003-2007. The highest growth rate was recorded by low-income countries $(7.5 \%)$, and the lowest growth rate by high income countries (3.2\%). However, nearly all of the EU countries registered negative growth rates during crisis years 2008-2009. Thus, the responsibility for reducing GDP is borne by all of them. The only country among the EU-27 with a positive average GDP growth rate for the period 2008-2009 was Poland (1.65\%). The growth rate tendency was just the opposite of that found by Dullien: the largest drop was found among the low income countries (without Poland), and a smaller drop among the other income groups. However, all four groups comprising the EU-27 contributed to the contraction in world GDP in 2009.

The inflation indicator is regarded as tightly connected with macroeconomic stability and economic growth. The data in Table 2 confirm the reverse relationship between inflation and GDP per capita. The same tendency is observed in the two studies: the lower the income per capita in the individual group, the higher the inflation.

The impact of the crisis varies with the size of the external imbalances of individual countries (Figure 7). In the case of the EU-27 countries' 2007 current account surpluses (Luxemburg, Sweden, Germany, Netherlands, Belgium, Denmark, Finland, and Austria) and the countries with lower current account deficits of up to 5\% (France, Italy, Czech Republic, Poland, and Slovenia), they register smaller changes in GDP growth due to the crisis than other countries. The following countries experienced the largest negative effect of the crisis related to the current account deficit: Latvia, Lithuania, Estonia, Ireland, Romania, Bulgaria, and others. The correlation coefficient be- 


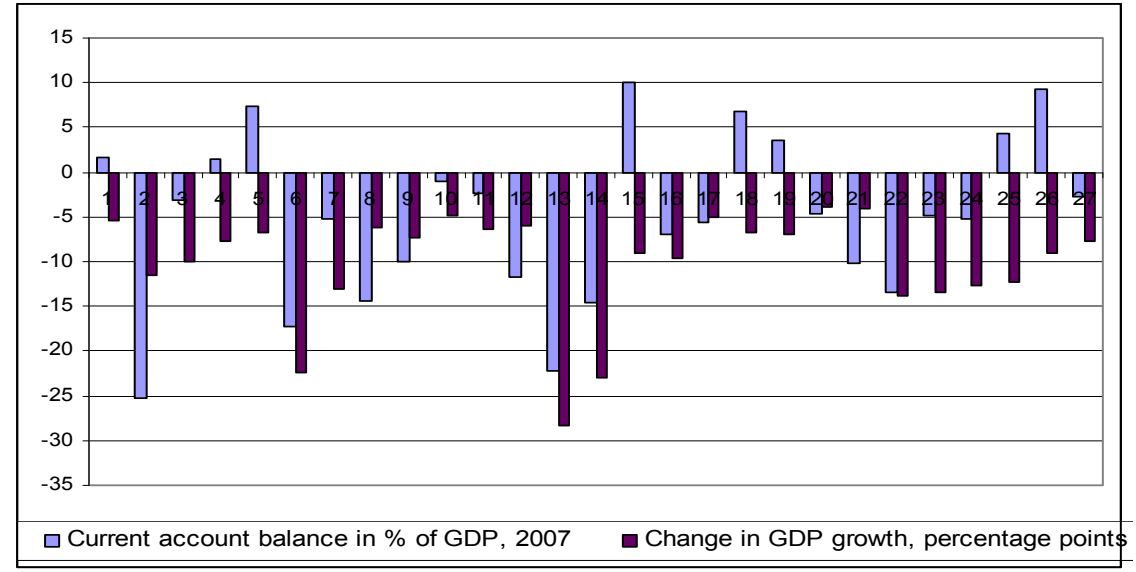

List of the countries: 1. Belgium, 2. Bulgaria, 3. Czech Republic, 4. Denmark, 5 Geramny, 6. Estonia, 7. Ireland, 8. Greece, 9. Spain, 10. France, 11. Italy, 12. Cyprus, 13. Latvia, 14. Lithuania, 15.

Luxembourg, 16. Hungary, 17. Malta, 18. Netherlands, 19. Austria, 20. Poland, 21. Portugal, 22.

Romania, 23. Slovenia, 24. Slovakia, 25. Finland, 26. Sweden, 27. United Kingdom.

Figure 7. Change in GDP growth between 2003-2007 and 2008-2009 by current-account position of countries in 2007

tween the two variables - current account balance in 2007 and changes in GDP growth is 0.512. Moreover, when the absolute current account balance is used, the correlation coefficient is higher but negative (-0.588). In general, this means that for a given country or group of countries, lower current account imbalances are associated with a better (positive) crisis experience.

We have further divided the EU-27 into four country groups according to their current-account positions prior to the crisis:

(a) Countries with a current account surplus of:

- more than 5\% of GDP: Austria, Belgium, Denmark, and Finland.

- less than 5\% of GDP: Germany, Luxembourg; Netherlands, and Sweden.

(b) Countries with a current account deficit of:

- less than 5\% of GDP: Czech Republic, France, Italy, Poland, Slovenia, and the United Kingdom - more than 5\% of GDP: Bulgaria, Cyprus, Estonia, Greece, Hungary, Ireland, Latvia, Lithuania, Malta, Portugal, Romania, Slovakia, and Spain.
The same grouping (for 179 countries) is made in Dullien's study. It can be observed that countries with large current account imbalances - surpluses or deficits - have been hit harder than those with moderate imbalances. The group with very high surpluses experienced the highest drop in growth by 4.2 percentage points, followed by a slightly smaller drop in growth of 3.9 percentage points for the group with very high deficits. In contrast, countries with moderate deficits or moderate surpluses experienced a decline of only 2.2 percentage points and 3.1 percentage points, respectively (Figure 8). Current account surpluses contributed to the crisis spread among the various countries and regions due to other macroeconomic imbalances that were present prior to the crisis in the form of insufficient domestic demand. Prior to the crisis, these countries relied on the domestic demand of other countries. However, in times of crisis, they must rely on (insufficient) demand in their own countries.

A similar tendency is observed for the sample of EU-27 countries (Figure 9). Countries with large cur- 


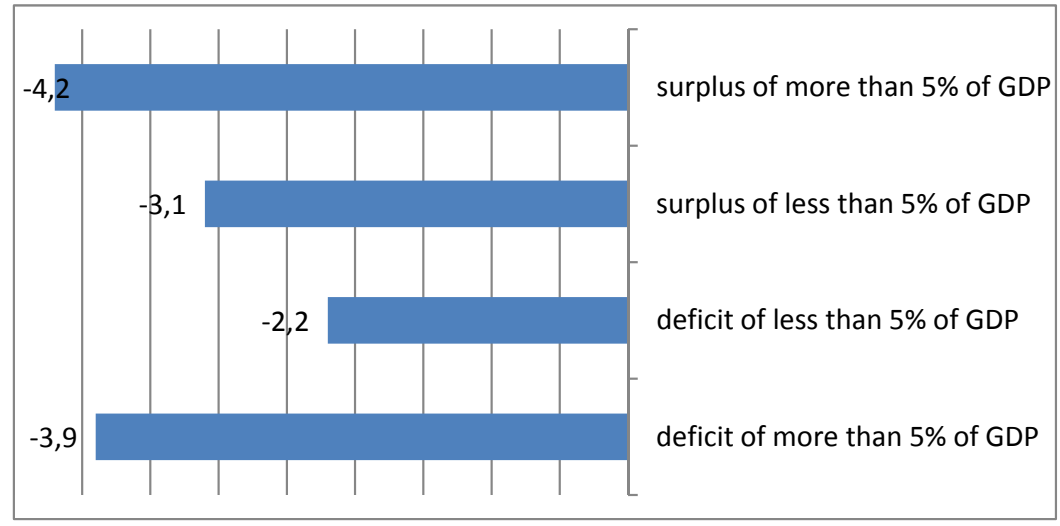

Figure 8. Change in GDP growth between 2003-2007 and 2008-2009 by current account position of 179 countries (percentage points). Adapted from Dullien, 2010 p. 104

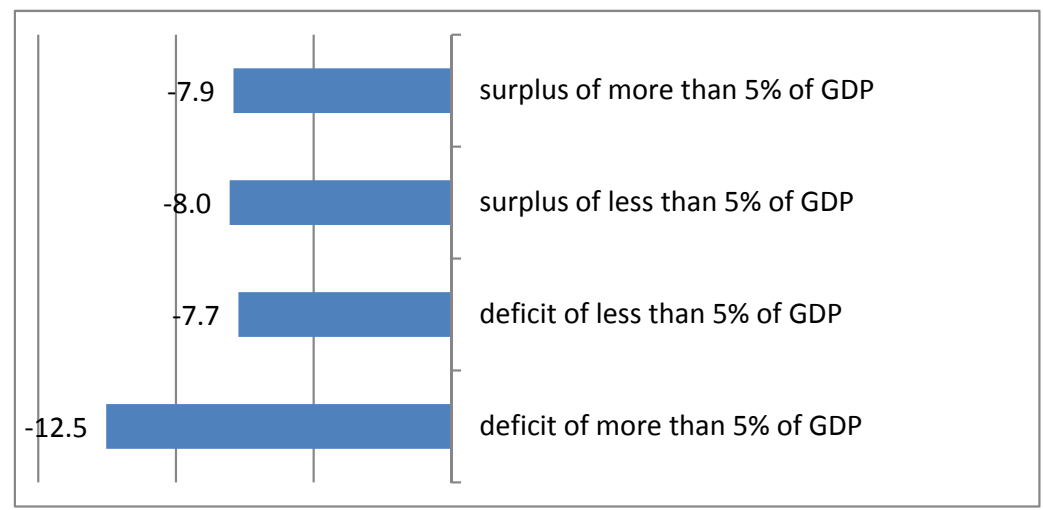

Figure 9. Change in GDP growth between 2003-2007 and 2008-2009 by current account position of the EU-27 countries (percentage points)

rent account imbalances - deficits or surpluses, together with the group of small surpluses (less than 5\% of GDP) - were hit harder by the crisis in terms of economic growth (by $12.5,7.9$, and 8.0 percentage points respectively) than those with moderate deficits (by 7.7 percentage points). Comparing the results of the two samples, we conclude that this tendency is more distinct among the 179 countries.
Considering the relationship between the current account position and average inflation of the countries or groups of countries prior to the crisis, we arrive at the following finding: the higher current-account deficits or surpluses, the higher the inflation (Table 3). Thus, once again, not only do current-account deficits appear to have contributed to the propagation of the crisis but also current-account surpluses. This tendency is more 
Table 3. Average inflation by current account position of countries in $2007, \%$

\begin{tabular}{lcc}
\hline & EU-27 & 179 countries \\
\hline Current account surplus of: & & \\
\hline More than 5\% of GDP & 2.08 & 7.5 \\
Less than 5\% of GDP & 1.83 & 3.8 \\
& & \\
Current account deficit of: & & 6.6 \\
Less than 5\% of GDP & 2.55 & 5.9 \\
More than 5\% of GDP & 4.53 & \\
\hline
\end{tabular}

Note: For EU countries, the author's calculations are based on Eurostat data. For the 179 countries, see (Dullien, 2010).

clearly outlined for the EU-27 and, in the case of the current-account surpluses, for the 179 countries.

\section{B. Regression estimates}

Descriptive statistics such as those above are not sufficient for arriving at more convincing conclusions. The question is whether the factors analyzed above have a direct influence on their own or only an indirect influence. To answer this question, a regression was run with the change in GDP growth between 2003-2007 and 2008-2009 as a dependent variable and the currentaccount balance prior to the crisis (2007), the inflation rate prior to the crisis (2007), and GDP per capita as independent (explanatory) variables. Based on his explanatory model, Dullien included additional variables in his study, such as capital account openness, a dummy for an IMF program in 2009 and dummies for the different types of exchange rate regimes, as possible factors influencing the average annual rate of GDP growth in 2008-2009 (Dullien, 2010). Variables that were insignificant, at least at the $10 \%$ level, were eliminated. Where the impact was measured as a change in growth rate, the results indicated that only per capita GDP levels and current-account imbalances had a clearly negative influence on the way a country was affected by the crisis (both coefficients were significant at the 5\% level). In addition, both the current-account balance and the absolute value of the current-account balance were alternatively included to allow for the possibility that large surpluses also make a country vulnerable.

The final equation for the change in growth trend of the 179 countries-sample during the crisis is the following:
$\Delta$ growth $=-2.27-0.428$ GDPcapita +

- 0.07|CurrentAccount2007|,

where $\Delta$ growth is the percentage point change in the average annual growth rate between 2003-2007 and 2008-2009, GDPcapita is GDP per capita in current USD, and |CurrentAccount2007| is the absolute value of the current account in 2007 in \% of GDP.

Using the data for the EU-27, the equation for the change in the growth trend of this group of countries during the crisis is the following;

$\Delta$ growth $=-6.861+0.049$ GDPcapita +

- 0.535|CurrentAccount2007|,

R square $=0.353$

Standard Errors of the Estimate $=5.045$

Equations (1) and (1a) lead to the following findings:

- For the sample of 179 countries, those with higher per capita incomes were hit significantly harder by the crisis than those with lower incomes. In the case of the EU-27, those countries with lower GDP per capita were hit harder, but their weight in the EU's average growth rate change is small.

- Interestingly, the current-account balance as percent of GDP was insignificant in explaining the change in GDP growth, whereas the absolute value of the current-account balance as a percent of GDP turned was highly significant (to varying degrees for the two groups of countries). This means that the magnitude of the current-account imbalances (regardless of whether they are surpluses or deficits) is the impor- 
tant factor for the smaller change in the average annual growth rate between 2003-2007 and 2008-2009.

Further, a regression analysis of the current-account balance prior to the crisis (2007) was conducted. The inflation rate prior to the crisis (2007), the GDP growth rate prior to the crisis (2003 to 2007), and GDP per capita were identified as possible factors influencing the average annual rate of GDP growth in 2008-2009. For the 179-country sample, all variables were significant at the $5 \%$ level except inflation and the GDP growth rate for the period 2003-2007, which was significant at $10 \%$. For the EU-27 sample, all variables were significant at the $5 \%$ level.

The resulting equation for the 179 countries, including a dummy for the country using a currency board variable, is:

growth2008_9 $=1.69+0.16$ growth2003_7 + +0.05 CurrentAccount2007 - 0.74GDPcapita + +0.08 inf $2007-2.01 \mathrm{cb}$,

where growth2008_9 is the average annual growth rate of GDP in 2008 and 2009, growth2003_7 is the average annual growth rate of GDP during 2003-2007, CurrentAccount2007 is the current account position as a percent of GDP in 2007, inf2007 is the rate of inflation in 2007 and cb is a dummy for countries with a currency board.

Using the relevant data for the EU-27 and including a dummy variable for the EU New Member Countries (nmc) instead of $\mathrm{cb}$ in equation (2), we obtain the following equation:

growth2008_9 $=-0.382-0.276$ growth2003_7 + - 0.085CurrentAccount2007+0.082GDPcapita+

-0.122 inf $2007+3.037 \mathrm{nmc}$

R square $=0.763$

Standard Errors of the Estimate $=1.264$

With respect to equations (2) and (2a), we arrive at the following findings:

- Countries that experienced strong growth prior to the crisis reversed course and entered deep recessions. Among the EU-27 countries, the highest average GDP growth rate prior to the crisis was registered mainly by the low income NMCs (7.46\%) that, through the 2000s, followed a persistent policy of catching up to the level of development of the leading countries. They are followed by the middle low-income countries (5.02\%), middle high-income countries (4.52\%) and high income countries (3.20\%), i.e., the main countries in the Euro area. Concerning the 179-country sample, the growth rates across the same groups are as follows: $5.4 \% ; 6.1 \% ; 5.9 \%$ and $4.5 \%$.

- For the sample of 179 countries, GDP per capita was a very strong predictor of lower growth during the crisis years. One reason for this may be that the crisis originated in some of the most developed countries. In the case of the EU-27, GDP per capita is a weak predictor in a different way for lower growth in the crisis years.

- The current-account deficit, not its absolute value, seems to be a significant variable for the two samples. A larger deficit prior to the crisis led to lower growth during the crisis years. The relationship is the opposite for the EU-27 due to the aforementioned negative signs of the average annual growth rates of GDP in 2008 and 2009 for all countries without Poland.

- According to the two regressions, a higher rate of inflation prior to the crisis is correlated with a higher drop in the growth rate during the crisis (even when controlling for GDP growth prior to the crisis).

- Countries with a currency board in place in the 179-country sample had a significantly lower growth rate in 2008-2009 (on average, by $2 \%$ annually) even after controlling for the effects of the large current-account deficits some of the currency board countries, such as Lithuania and Estonia, were running prior to the crisis.

We can modify the equation for the EU-27 to verify the discovered relationships or to enrich the analysis. Using the aforementioned fact that the correlation coefficient of the absolute current account balance and the changes in GDP growth (-0.588) are higher but negative compared to those of the current account (0.512), we replace the latter variable with the former, run the regression and obtain the following results:

growth2008_9 $=0.023-0.276$ growth2003_7 + $+0.134 \mid$ CurrentAccount2007 $\mid+0.51$ GDPcapita +

-0.230 inf $2007+3.099 \mathrm{nmc}$

R square $=0.786$

Standard Errors of the Estimate $=1.203$ 
Judging by the correlation coefficient R-square $(0.786)$ in (3a), the latter equation has better approximation than (2a). All variables are significant at the 5\% level. Although the role of the 2003-2007 GDP growth rate is the same in (2a) and (3a), and other variables remain nearly the same (GDP per capita, average inflation, dummy variable), the absolute current account balance is the only variable that changes the relationship in the opposite direction. This means that for the EU-27 countries, not only is the larger current account deficit prior to the crisis important (which led to lower growth during the crisis years) but also the larger value of the current account imbalances (whether deficits or surpluses).

In the 179-country regression, inflation prior to the crisis seems to have influenced the impact of the crisis, but not in the way that would be predicted by the standard theory. In the standard model, a higher rate of inflation prior to the crisis was correlated with a higher growth rate during the crisis. In the case of the EU-27, the lower rate of inflation prior to the crisis is correlated with a higher growth rate during the crisis. The latter finding is in accordance with the prediction of the standard theory.

\section{Conclusions}

1. At a global scale, the crisis appears to have affected high- and upper middle-income countries more than poorer countries. There may have been greater suffering in lower income countries, because a drop in GDP growth might be more severe in an environment without social safety nets, and widespread poverty resulted from the crisis. This means that having a higher GDP per capita generally increases the risk of experiencing a severe recession. In the case of the EU-27 countries, the crisis appears to have affected lower income countries more than higher income countries.

2. The two sample regression analyses reveal the following tendency: experiencing very strong growth in the years 2003-2007 (just prior to the crisis) seems to have increased the risk of the crisis plunging a country into a deep recession. This finding hints that a boom prior to the crisis may have led to imbalances, rendering the economy in question more vulnerable (because the country may have been part of a boom-and-bust cycle).
3. Large current-account imbalances - not only deficits but also surpluses - prior to the crisis are also an important risk factor for the two groups of countries. In the case of the EU-27, absolute current-account imbalances seem to be a more important risk factor for vulnerability to crisis transmission.

4. Inflation, long a prime concern for macroeconomic stability and an important factor in increasing a country's vulnerability to financial and currency crises, does not seem to be as significant a factor as previously believed.

\section{References:}

Blanchard, O., Milesi-Ferretti, G. M. (2009). Global Imbalances: In Midstream? International Monetary Fund. (Working Paper No. 09/29). International Monetary Fund.

Dullien, S. (2010). Risk Factors in International Financial Crises: Early Lessons from the 2008-2009 Turmoil. In S. Dullien, D. J. Kotte, A. Márquez, J. Priewe (Eds.), The Financial and Economic Crisis of 2008-2009 and Developing Countries (pp. 99116). New York, NY: UNCTAD, United Nations.

EUROSTAT (2014a). Real GDP growth rate - volume, Percentage change on previous year. Retrieved from http://epp.eurostat.ec.europa.eu/tgm/table. $\mathrm{do} ? \mathrm{tab}=$ table\&init $=1$ \&plugin $=1$ \&language $=\mathrm{en} \& \mathrm{p}$ code $=$ tec 00115

EUROSTAT (2014b). Balance of the current account, $\%$ of GDP. Retrieved from: http://epp.eurostat. ec.europa.eu/tgm/table.do?tab=table\&language $=$ en $\&$ pcode $=$ tec 00043

EUROSTAT (2014c). HICP - inflation rate. Annual average rate of change (\%). Retrieved from: http:// epp.eurostat.ec.europa.eu/tgm/table.do?tab=table \&plugin $=1$ \&language $=$ en $\&$ pcode $=$ tec 00118

International Monetary Fund (2010). World Economic Outlook. (April 2010). Rebalancing Growth. Retrieved from https://www.sagia.gov.sa/Documents/ Reports/world_Economic_Outlook_2010.pdf

Ocampo, J. A., Griffith-Jones, S., Noman, A., Ortiz, A., Vallejo, J., \& Tyson, J. (2010). The Great Recession and the Developing World. Paper prepared for Conference on Development Cooperation in Times of Crisis and on Achieving the MDGs. IFEMA Convention Centre (Madrid), 9-10 June 2010. Retrieved from: http://www.stephanygj.net/ 
papers/TheGreatRecessionandTheDevelopingWorld2010.pdf

Priewe, J. (2010). What Went Wrong? Alternative Interpretations of the Global Financial Crisis. In S. Dullien, D. J. Kotte, A. Márquez, J. Priewe (Eds.), The Financial and Economic Crisis of 2008-2009 and Developing Countries (pp.17-52). New York, NY: UNCTAD, United Nations.

OECD (2012). Current account balance of payments as a percentage of GDP. Trade: Key tables from OECD. Retrieved from http://www.oecdilibrary.org/trade/current-account-balance-ofpayments_20743920-table5

World Bank (2014a). World Bank Data: Current account balance (\% of GDP). Retrieved from: http:// data.worldbank.org/indicator/BN.CAB.XOKA. GD.ZS?page $=1$

World Bank (2014b). World Bank Data:GDP growth (annual \%). Retrieved from: http://data.worldbank.org/indicator?NY.GDP.MKTP.KD.ZG/ countries 
